\title{
Surface Properties and Micelle Formation of a Series of Alkyl Octakis(oxyethylene) Ethers in the Aqueous Solutions and Their Temperature Dependences
}

\author{
Minoru UENo, Yōsuke TAKASAwA, Yūjin TABATA*, \\ Takamitsu SAWAMURA, Nobuo KaWAHASHI, and \\ Kenjiro MEGURO \\ Department of Chemistry, Faculty of Science, Science University of \\ Tokyo (1-3, Kagurazaka, Shinjuku-ku, Tokyo). \\ * Nihon Surfactants Inc. Co. (3-24-3, Hasune, Itabashi-ku, Tokyo)
}

\begin{abstract}
The values of cmc, area per molecule and equilibrium surface tension at $\mathrm{cmc}$ of a homologous series of alkyl octakis (oxyethylene) ethers $\left(\mathrm{C}_{n} \mathrm{E}_{8}: n=10\right.$ to 15$)$ were determined from the concentration dependence of surface tension in the temperature range $15.0^{\circ} \mathrm{C}$ to $40.0^{\circ} \mathrm{C}$. The areas per molecule and equilibrium surface tension values at the cmc decreased with an increasing carbon number and they showed zigzag curves by the difference in even and odd carbon numbers. These findings may be attributed to the difference in the molecular orientation between the molecules with even carbon number and ones with odd carbon number on the air-water interface.

On the other hand, the plots of log cme vs. the number of carbon atoms $(N)$ in the alkyl chain exhibited a linear relationship, and the difference between even and odd carbon numbers was not observed on the bulk properties. The free energy change relating to micelle formation, $\Delta G_{m}$, was calculated from the temperature dependence of the cmc. $\Delta H_{m}$ and $\Delta S_{m}$ values were estimated from the slopes and the intercepts of the $\log \mathrm{cmc}$ versus the reciprocal of temperature plots, respectively. This result indicates that $\Delta S_{m}$ dominates over the micellization. Furthermore, the values of $\Delta G_{m}\left(-\mathrm{CH}_{2}-\right), \Delta H_{m}\left(-\mathrm{CH}_{2}-\right)$, $\Delta S_{m}\left(-\mathrm{CH}_{2}-\right)$ and $T \Delta S_{m}\left(-\mathrm{CH}_{2}-\right)$ per methylene group calculated from the slope of each thermodynamic parameter against the carbon number were $-0.68 \mathrm{kcal} / \mathrm{mol},-0.33 \mathrm{kcal} / \mathrm{mol}, 1.16 \mathrm{cal} /(\mathrm{mol} \cdot \mathrm{deg})$, and $0.35 \mathrm{kcal} / \mathrm{mol}$, respectively. $\mathrm{It}_{1}$ was concluded that the summation of $\Delta H_{m}\left(-\mathrm{CH}_{2}-\right)$ and $T \Delta S_{m}\left(-\mathrm{CH}_{2}-\right)$ contributed to the micellization.
\end{abstract}

\section{Introduction}

Although many investigations ${ }^{1) \sim 5)}$ have so far been reported with respect of surface and micellar properties of alkyl poly(oxyethylene) ethers having a Poisson distribution of the ethylene oxide chain and further with an alkyl chain comprising even carbon numbers, relative= $\left(y^{6) \sim 8)}\right.$ few studies have been carried out for a series of alkyl poly(oxyethylene) ethers with an alkyl chain comprising even and odd carbon numbers and in addition with a homogeneous ethylene oxide chain.

In this work, surface tensions for such a series of alkyl octakis(oxyethylene) ethers $\left(\mathrm{C}_{n} \mathrm{E}_{8}: n=10\right.$ to 15$)$ with a homogeneous octac ethylene oxide chains and further with an alkyl chain consisting of either even or odd carbon numbers are measured in aqueous solus tions in the temperature range from $15.0^{\circ} \mathrm{C}$ to $40.0^{\circ} \mathrm{C}$. The effects of the temperature and of the difference in even and odd carbon numbers among their surfactant molecules on the surface area per molecule at air-water interface and on the micellization will be discussed on the basis of the experimentally obtained data and also the thermodynamic parameters calculated from the surface tension measurements. 


\section{Experimental procedures}

\subsection{Materials}

Alkyl octakis (oxyethylene) ethers $\mathrm{C}_{n} \mathrm{H}_{2 n+1} \mathrm{O}$ $\left(\mathrm{CH}_{2} \mathrm{CH}_{2} \mathrm{O}\right)_{8} \mathrm{H}\left(\mathrm{C}_{n} \mathrm{E}_{8} ; n=10\right.$ to 15$)$ were sup= plied by Nikko Chemicals Co., Tokyo, Japan. The homogeneity of the octakis(oxyethylene) chain was confirmed by TLC. The purity was found by GLC to be in excess of $99.0 \%$. Traces of impurity nondetectable by TLC and GLC were removed by repeated passage through a gel permeation chromatographic column until the minimum in the surface tension curves and the corresponding peak in the GPC chromato= gram disappeared. The identical process was used to purify all samples.

Water was purified by passing through a Milli-Q system (Nihon Millipore Co.) until its specific conductivity fell below $10^{-7} \cdot \Omega^{-1} \cdot \mathrm{cm}^{-1}$.

\subsection{Measurements}

Surface tensions of the surfactant solutions prepared by dilution of the mother liquor were measured with a modified Wilhelmy type sur= face tensiometer SHIMADZU ST-1. Measure= ments were performed at 15.0, 20.0, 25.0, 30.0 and $40.0 \pm 0.1^{\circ} \mathrm{C}$. Equilibrium reachings were taken between 1 and $2 \mathrm{~h}$. This time interval was acceptable even for the lowest concentration of surfactant solutions. The estab= lishment of equilibrium was checked by re= peated measurements in $5 \mathrm{~min}$ intervals after reaching $1 \mathrm{~h}$.

\section{Results and discussion}

Surface tensions as a function of solute con= centrations of $\mathrm{C}_{n} \mathrm{E}_{8}(n=10$ to 15$)$ were measured in the temperature range from $15.0^{\circ} \mathrm{C}$ to $40.0^{\circ} \mathrm{C}$. The typical curves are given for $\mathrm{C}_{10} \mathrm{E}_{8}$ and $\mathrm{C}_{13} \mathrm{E}_{8}$ in Figs.-1 (a) and (b), respectively. Some surface properties and $\mathrm{cmc}$ of $\mathrm{C}_{n} \mathrm{E}_{8} \mathrm{ob}=$ tained from their curves are summarized in Table-1.

The molecular area values in Table-1 calcu= lated by using the Gibbs adsorption isotherm equation from the slopes of the curves below the sharp breaks at their $\mathrm{cmc}$ in the tempera= ture range $15.0^{\circ} \mathrm{C}$ to $40.0^{\circ} \mathrm{C}$ are plotted in Fig. -2 against the number of carbon atoms $(N)$ in the alkyl chain.

These plots are zigzag in the difference of

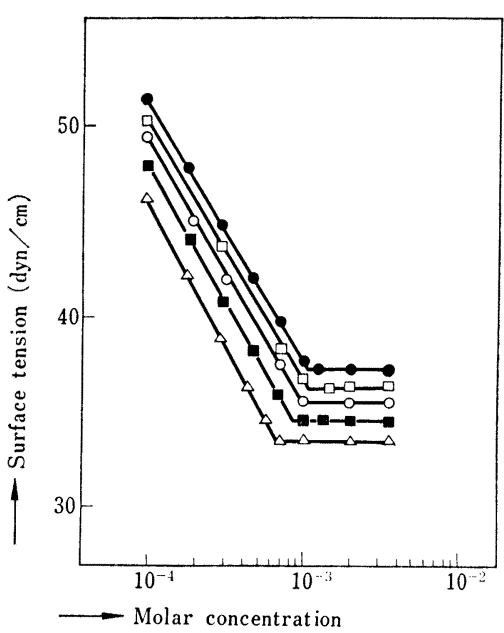

$-\bigcirc: 15.0^{\circ} \mathrm{C},-\square-: 20.0^{\circ} \mathrm{C},-\bigcirc-$ : $25.0^{\circ} \mathrm{C},-\square-: 30.0^{\circ} \mathrm{C},-\triangle-: 40.0^{\circ} \mathrm{C}$

Fig.-1 (a) Plots of surface tension against the logarithm of the solute concentra $=$ tions for $\mathrm{C}_{10} \mathrm{E}_{8}$ at given temper= atures.

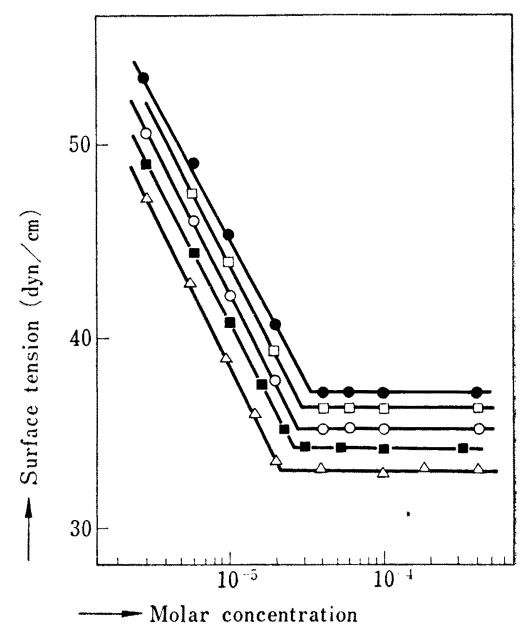

- - : $15.0^{\circ} \mathrm{C},-\square-: 20.0^{\circ} \mathrm{C},-\bigcirc-$ :

$25.0^{\circ} \mathrm{C},-\square-: 30.0^{\circ} \mathrm{C},-\triangle-: 40.0^{\circ} \mathrm{C}$.

Fig.-1 (b) Plots of surface tension against the logarithm of the solute con= centrations for $\mathrm{C}_{13} \mathrm{E}_{8}$ at given temperatures.

the even-odd numbered carbon atoms, and the molecular area values decrease with an increase of the alkyl chain length. The zigzag line can be shown by two separate dashed lines among the surfactants with even carbon number and those with odd number in Fig.-2. The upper 
Table-1 Some surface properties and $\mathrm{cmc}$ obtained from surface tension curves in the tempe $=$ rature range from $15.0^{\circ} \mathrm{C}$ to $40.0^{\circ} \mathrm{C}$.

\begin{tabular}{|c|c|c|c|c|c|}
\hline $\begin{array}{c}\text { Temp. } \\
\left({ }^{\circ} \mathrm{C}\right)\end{array}$ & $\mathrm{cmc}(\mathrm{M})$ & $\begin{array}{c}\gamma_{\mathrm{cmc}} \\
(\mathrm{dyn} / \\
\mathrm{cm})\end{array}$ & $\begin{array}{l}-\partial \gamma / \partial \\
\log C\end{array}$ & $\begin{array}{c}\Gamma(\mathrm{mol} / \\
\left.\mathrm{cm}^{2}\right) \\
\times 10^{10}\end{array}$ & $\begin{array}{c}A \\
\left(\AA^{2}\right)\end{array}$ \\
\hline $\mathrm{C}_{10} \mathrm{E}_{8}$ & $1.4 \times 10^{-3}$ & 37.3 & 12.49 & 2.26 & 73.5 \\
\hline 20 & $1.2 \times 10^{-3}$ & 36.5 & 13.35 & 2.38 & 69.8 \\
\hline 25 & $1.0 \times 10^{-3}$ & 35.5 & 13.80 & 2.42 & 68.6 \\
\hline 30 & $9.3 \times 10^{-4}$ & 34.4 & 14.42 & 2.48 & 66.9 \\
\hline 40 & $7.6 \times 10^{-4}$ & 33.5 & 15.15 & 2.53 & 65.6 \\
\hline $\mathrm{C}_{11} \mathrm{E}_{8}{ }_{15}$ & $4.0 \times 10^{-4}$ & 36.8 & 13.00 & 2.36 & 70.4 \\
\hline 20 & $3.5 \times 10^{-4}$ & 36.0 & 13.82 & 2.46 & 67.5 \\
\hline 25 & $3.0 \times 10^{-4}$ & 35.3 & 14.36 & 2.50 & 66.4 \\
\hline 30 & $2.7 \times 10^{-4}$ & 34.0 & 14.88 & 2.56 & 64.9 \\
\hline 40 & $2.3 \times 10^{-4}$ & 33.3 & 15.63 & 2.61 & 63.6 \\
\hline $\mathrm{C}_{12} \mathrm{E}_{8}{ }_{15}$ & $9.7 \times 10^{-5}$ & 36.0 & 14.52 & 2.63 & 63.1 \\
\hline 20 & $8.3 \times 10^{-5}$ & 35.0 & 15.06 & 2.68 & 62.0 \\
\hline 25 & $7.1 \times 10^{-5}$ & 34.3 & 15.50 & 2.72 & 61.1 \\
\hline 30 & $6.9 \times 10^{-5}$ & 33.4 & 16.14 & 2.78 & 59.7 \\
\hline 40 & $5.8 \times 10^{-5}$ & 32.7 & 16.88 & 2.82 & 58.9 \\
\hline $\mathrm{C}_{13} \mathrm{E}_{8}{ }_{15}$ & $3.2 \times 10^{-5}$ & 36.5 & 15.62 & 2.83 & 58.7 \\
\hline 20 & $2.8 \times 10^{-5}$ & 35.8 & 16.14 & 2.87 & 57.9 \\
\hline 25 & $2.7 \times 10^{-5}$ & 34.9 & 16.40 & 2.87 & 57.9 \\
\hline 30 & $2.5 \times 10^{-5}$ & 33.8 & 16.86 & 2.90 & 57.3 \\
\hline 40 & $2.0 \times 10^{-5}$ & 32.8 & 17.52 & 2.92 & 56.9 \\
\hline $\mathrm{C}_{14} \mathrm{E}_{8}{ }_{15}$ & $1.1 \times 10^{-5}$ & 35.7 & 18.36 & 3.33 & 49.9 \\
\hline 20 & $9.8 \times 10^{-6}$ & 35.0 & 18.75 & 3.34 & 49.7 \\
\hline 25 & $9.0 \times 10^{-6}$ & 34.0 & 19.00 & 3.33 & 49.9 \\
\hline 30 & $8.0 \times 10^{-6}$ & 33.2 & 19.48 & 3.35 & 49.6 \\
\hline 40 & $7.2 \times 10^{-6}$ & 32.3 & 20.10 & 3.35 & 49.6 \\
\hline $\mathrm{C}_{15} \mathrm{E}_{8}$ & $4.1 \times 10^{-6}$ & 36.0 & 20.35 & 3.69 & 45.0 \\
\hline 20 & $3.7 \times 10^{-6}$ & 35.2 & 20.66 & 3.68 & 45.1 \\
\hline 25 & $3.5 \times 10^{-6}$ & 34.3 & 20.95 & 3.67 & 45.2 \\
\hline 30 & $3.2 \times 10^{-8}$ & 33.5 & 21.37 & 3.68 & 45.1 \\
\hline 40 & $3.0 \times 10^{-6}$ & 32.6 & 22.01 & 3.67 & 45.2 \\
\hline
\end{tabular}

line is for the surfactants with odd carbon number and the lower one for those with even carbon number. It is evident from these find = ings in Fig.-2 that the molecular orientation of the former with odd carbon number on the air-water interface is a little different from that of the latter with the even carbon number. This suggests that the packing for the former on the air-water interface is more loosely than that for the latter.

Temperature dependences of their molecular areas decreased with the increase of hydrocar= bon chain length, but were not observed for

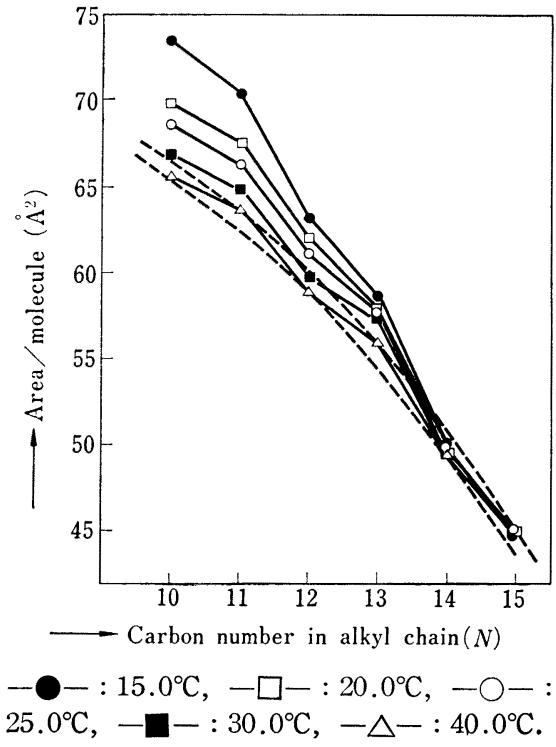

Fig.-2 Plots of aera per molecule at the air-water interface at the $\mathrm{cmc}$ against the number of carbon atoms $(N)$ in the alkyl chain of $\mathrm{C}_{n} \mathrm{E}_{8}$.

$\mathrm{C}_{14} \mathrm{E}_{8}$ and $\mathrm{C}_{15} \mathrm{E}_{8}$ as shown in Fig. -2 and mole= cular areas for the two surfactants showed almost the same value in all temperature range from $15.0^{\circ} \mathrm{C}$ to $40.0^{\circ} \mathrm{C}$. This suggests that, whereas the increase of the molecular motion caused by rising temperature decreases the amount of the adsorption on the water surface, it increases due to dehydration of ethylene oxide chain in the molecule with rising temperature, and in the case of $\mathrm{C}_{14} \mathrm{E}_{8}$ and $\mathrm{C}_{15} \mathrm{E}_{8}$, two oppos site effects ${ }^{2,9), 10)}$ are compensated each other.

In a similar manner as in the case of the molecular area data, the plots of the equilibrium surface tension at the $\mathrm{cmc} v s$. carbon number $(N)$ at the given temperatures, as shown in Fig.-3, exhibited a zigzag line and the surface tension values decreased with the increase of the carbon number $(N)$ and temperature.

This zigzag line is also represented by two different curves as shown in Fig.-3. The upper line is for the surfactants with odd carbon number, and the lower line for even carbon number. This gives a stronger support to the findings obtained from the molecular area data that the adsorption amount is larger for the surfactant with even carbon' number than that 


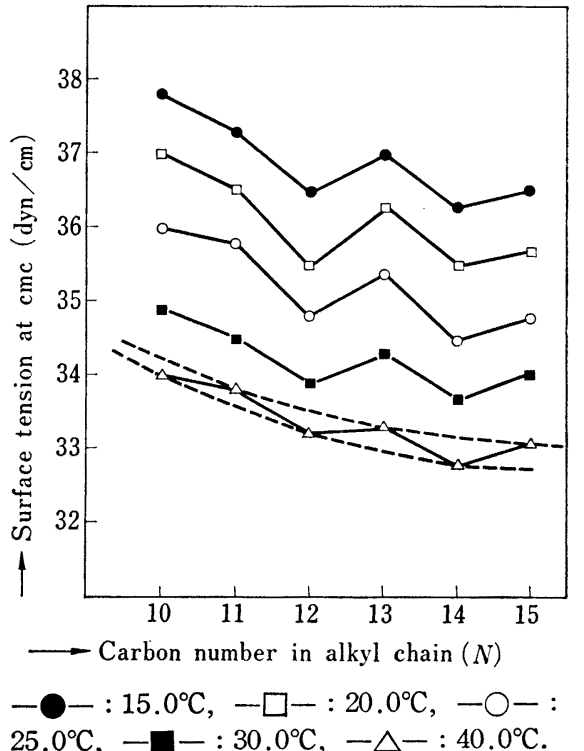

Fig.-3 Plots of surface tension at the $\mathrm{cmc}$ against the number of carbon atoms $(N)$ in the alkyl chain of $\mathrm{C}_{n} \mathrm{E}_{8}$ in the temperature range from $15.0^{\circ} \mathrm{C}$ to $40.0^{\circ} \mathrm{C}$.

for one with odd number.

Plots of $\log \mathrm{cmc} v s$. the number of carbon atoms $(N)$ in the alkyl chain exhibit a linear relationship $^{10), 11)}$ as shown in Fig.-4.

The linear relationships in the temperature

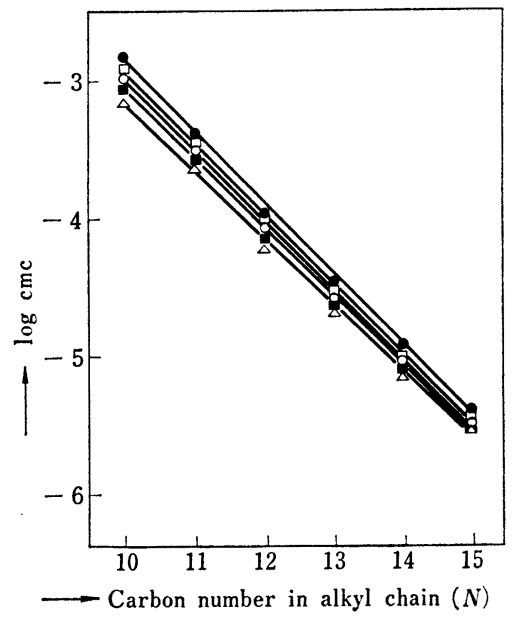

- - : $15.0^{\circ} \mathrm{C},-\square-: 20.0^{\circ} \mathrm{C},-\bigcirc-$ :

$25.0^{\circ} \mathrm{C},-\square-: 30.0^{\circ} \mathrm{C},-\triangle-: 40.0^{\circ} \mathrm{C}$.

Fig.-4 Plots of $\log \mathrm{cmc}$ at given tem= peratures against the number of carbon atoms $(N)$ in the alkyl chain of $\mathrm{C}_{n} \mathrm{E}_{s}$. range from $15.0^{\circ} \mathrm{C}$ to $40.0^{\circ} \mathrm{C}$ are given by the following general equation.

$\log \mathrm{cmc}=A_{1} N+B_{1}$

The constants of $A_{1}$ and $B_{1}$ are summarized in Table-2.

Table-2 The constants corresponding to Eq. (1) and Eq. (3).

\begin{tabular}{c|c|c|c|c}
\hline $\begin{array}{c}\text { Temp. } \\
\left({ }^{\circ} \mathrm{C}\right)\end{array}$ & $A_{1}$ & $B_{1}$ & $A_{2} \times 10^{-3}$ & $B_{2} \times 10^{-3}$ \\
\hline 15.0 & -0.51 & 2.18 & -0.67 & 0.58 \\
20.0 & -0.51 & 2.07 & -0.68 & 0.44 \\
25.0 & -0.50 & 1.89 & -0.68 & 0.21 \\
30.0 & -0.50 & 1.86 & -0.69 & 0.17 \\
40.0 & -0.48 & 1.66 & -0.69 & -0.12 \\
\hline
\end{tabular}

Table-3 Thermodynamic parameters for micellization of $\mathrm{C}_{n} \mathrm{E}_{8}$.

\begin{tabular}{|c|c|c|c|c|}
\hline $\begin{array}{l}\text { Temp. } \\
\left.\text { ( }{ }^{\circ} \mathrm{C}\right)\end{array}$ & $\left|\begin{array}{c}\Delta G_{m} \\
\left(\mathrm{kcal} \cdot \mathrm{mol}^{-1}\right)\end{array}\right|$ & $\mid \begin{array}{c}\Delta H_{m} \\
\left(\mathrm{kcal} \cdot \mathrm{mol}^{-1}\right)\end{array}$ & $\begin{array}{c}T \Delta S_{m} \\
\left(\mathrm{kcal} \cdot \mathrm{mol}^{-1}\right) \\
\end{array}$ & $\begin{array}{c}\Delta S_{m} \\
\left(\mathrm{cal} \cdot \mathrm{mol}^{-1}\right. \\
\left.\cdot \mathrm{deg}^{-1}\right)\end{array}$ \\
\hline${ }_{15}^{\mathrm{C}_{10} \mathrm{E}_{8}}$ & -6.06 & 4.41 & 10.49 & 36.4 \\
\hline 20 & -6.25 & 4.41 & 10.66 & 36.4 \\
\hline 25 & -6.46 & 4.41 & 10.85 & 36.4 \\
\hline 30 & -6.62 & 4.41 & 11.03 & 36.4 \\
\hline 40 & -6.96 & 4.41 & 11.37 & 36.4 \\
\hline $\mathrm{C}_{11} \mathrm{E}_{8}{ }_{15}$ & -6.77 & 3.99 & 10.76 & 37.4 \\
\hline 20 & -6.97 & 3.99 & 10.96 & 37.4 \\
\hline 25 & -7.18 & 3.99 & 11.15 & 37.4 \\
\hline 30 & -7.36 & 3.99 & 11.35 & 37.4 \\
\hline 40 & -7.71 & 3.99 & 11.70 & 37.4 \\
\hline${ }_{12}^{\mathrm{C}_{12} \mathrm{E}_{8}}$ & -7.59 & 3.66 & 11.25 & 39.1 \\
\hline 20 & -7.81 & 3.66 & 11.47 & 39.1 \\
\hline 25 & -8.04 & 3.66 & 11.66 & 39.1 \\
\hline 30 & -8.19 & 3.66 & 11.85 & 39.1 \\
\hline 40 & -8.56 & 3.66 & 12.22 & 39.1 \\
\hline${ }_{13}^{C_{13} E_{8}}$ & -8.22 & 3.28 & 11.50 & 39.9 \\
\hline 20 & -8.44 & 3.28 & 11.72 & 39.9 \\
\hline 25 & -8.61 & 3.28 & 11.90 & 39.9 \\
\hline 30 & -8.80 & 3.28 & 12.08 & 39.9 \\
\hline 40 & -9.23 & 3.28 & 12.51 & 39.9 \\
\hline${ }_{14}^{\mathrm{C}_{14} \mathrm{E}_{8}}$ & -8.83 & 3.02 & 11.85 & 41.2 \\
\hline 20 & -9.05 & 3.02 & 12.07 & 41.2 \\
\hline 25 & -9.26 & 3.02 & 12.28 & 41.2 \\
\hline 30 & -9.48 & 3.02 & 12.50 & 41.2 \\
\hline 40 & -9.86 & 3.02 & 12.88 & 41.2 \\
\hline${ }_{15}^{\mathrm{C}_{15} \mathrm{E}_{8}}$ & -9.40 & 2.73 & 12.13 & 42.1 \\
\hline 20 & -9.62 & 2.73 & 12.35 & 42.1 \\
\hline 25 & -9.82 & 2.73 & 12.55 & 42.1 \\
\hline 30 & -10.04 & 2.73 & 12.77 & 42.1 \\
\hline 40 & -10.41 & 2.73 & 13.14 & 42.1 \\
\hline
\end{tabular}


Their linear relationships were not affected by the difference between even and odd carbon numbers differing from the results for the sur= face properties.

The standard free energy of micelle formation $\left(\Delta G_{m}\right)$ is calculated according to P. Malyneux ${ }^{12)}$ by the following equation.

$$
\Delta G_{m}=2.303 R T(\log \mathrm{cmc}-\log w)
$$

where $w$ is the molar concentration of water at the given temperature. $\Delta G_{m}$ values calculated by Eq. (2) are listed in Table-3.

These $\Delta G_{m}$ values decrease with increasing number of carbon atoms from $C_{10}$ to $C_{15}$ in the alkyl chain of alkyl octakis (oxyethylene) ethers and further with increasing temperature as listed up in Table-3.

By combining Eq. (2) with Eq. (1), Eq. (3) is obtained.

$$
\Delta G_{m}=A_{2} N+\mathrm{B}_{2}
$$

The constants of $A_{2}$ and $B_{2}$ in the temperature range from $15.0^{\circ} \mathrm{C}$ to $40.0^{\circ} \mathrm{C}$ are summarized in Table-2.

The free energy changes for micelle formation per methylene group, $\Delta G_{m}\left(-\mathrm{CH}_{2}-\right)$, are given from the slopes $\left(A_{2}\right)$ of Eq. (3). These values $\left(A_{2}\right)$ were constant for each given temperature and agreed with data ${ }^{13) \sim 15)}$ published previously.

For the interpretation of the negative sign before the constant term, 0.12 at temperature of $40.0^{\circ} \mathrm{C}$ in Table-2, Eq. (3) is divided into independent additive contributions of the com $=$ ponents in the amphiphile molecule according to Eq. $(4)^{16)}$.

$$
\begin{aligned}
\Delta G_{m} & =\Delta G_{m}\left(\mathrm{CH}_{3}^{-}\right)+(N-1) \Delta G_{m}\left(-\mathrm{CH}_{2}-\right) \\
& +\Delta G_{m}(-W)
\end{aligned}
$$

where $\Delta G_{m}\left(\mathrm{CH}_{3}-\right)$ and $\Delta G_{m}(-W)$ are the free energy changes for micellization of methyl group and hydrophilic group, respectively. Further= more, Eq. (3) at temperature of $40.0^{\circ} \mathrm{C}$ is represented by

$$
\Delta G_{m}=N \Delta G_{m}\left(-\mathrm{CH}_{2}-\right)-0.12
$$

The difference between Eqs. (4) and (5) is as follows ;

$$
\begin{aligned}
& \Delta G_{m}\left(\mathrm{CH}_{3}-\right)-\Delta G_{m}\left(-\mathrm{CH}_{2}-\right) \\
& \quad+\Delta G_{m}(-W)=-0.12
\end{aligned}
$$

Here, $\Delta G_{m}\left(\mathrm{CH}_{3}-\right)$ may be eliminated by the use of available data ${ }^{17), 18}$ from the solubility of liquid $n$-alkanes in water at $25^{\circ} \mathrm{C}$.

Thus, the free energy of the process

$$
\mathrm{C}_{n} \mathrm{H}_{2 n+2} \text { (aq.) } \longrightarrow \mathrm{C}_{n} \mathrm{H}_{2 n+2} \text { (liq.) }
$$

can be represented within $\pm 0.04 \mathrm{kcal} / \mathrm{mol}$ for $n=5$ to 8 by the contributions

$$
\begin{gathered}
\Delta G\left(-\mathrm{CH}_{2}^{-}\right)=-0.85 \mathrm{kcal} / \mathrm{mol} ; \\
\Delta G\left(\mathrm{CH}_{3}-\right)=-2.18 \mathrm{kcal} / \mathrm{mol}
\end{gathered}
$$

Therefore, if we apply these parameters to micellization, it follows from Eq. (6) that

$$
\Delta G_{m}(-W)=1.21 \frac{\mathrm{kcal}}{\mathrm{mol}}
$$

It is evident that the positive value of $\Delta G_{m}$ ($W)$ means the opposition to micellization. Con= sequently, as the constant term of -0.12 in Eq. (3) at temperature of $40.0^{\circ} \mathrm{C}$ includes the contributions of $\Delta G_{m}(-W)$ and of the differ= ence between $\Delta G_{m}\left(\mathrm{CH}_{3}-\right)$ and $\Delta G_{m}\left(-\mathrm{CH}_{2}{ }^{-}\right)$, the sign before the constant term becomes negative due to larger contribution of methyl group than one of hydrophilic group.

The log cmc for each homolog in the series was plotted versus the reciprocal of tempera= tures as shown in Fig. $-\mathbf{5}$.

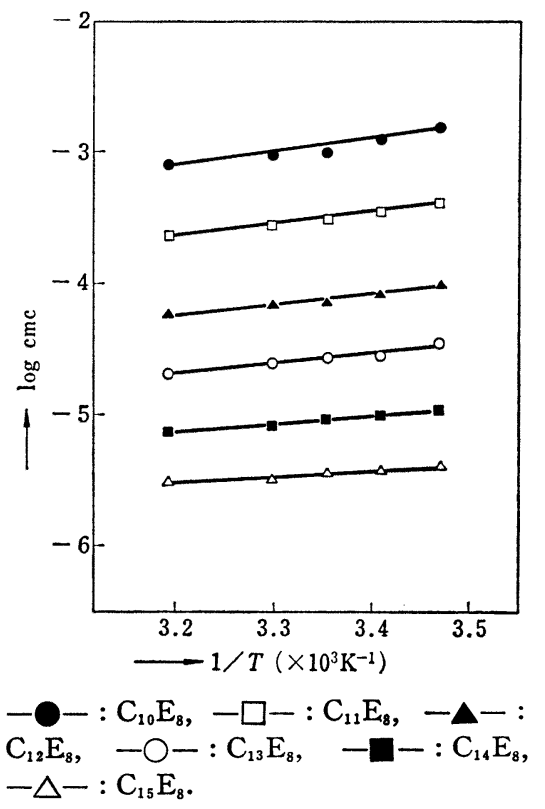

Fig. -5 Plot of $\log \mathrm{cmc}$ against the reciprocal of temperature $(1 / T)$.

As these $\log$ cmc versus $1 / T$ curves are nearly linear, they can be expressed by the following equation.

$$
\log \mathrm{cmc}=\frac{A_{3}}{T}+B_{3}
$$

The constants of $A_{3}$ and $B_{3}$ of $\mathrm{C}_{n} \mathrm{E}_{8}$ are given in Table-4.

The corresponding $\Delta H_{m}$ and $\Delta S_{m}$ values may 
Table-4 The constnat of each $\mathrm{C}_{n} \mathrm{E}_{8}$ corresponding to Eq. (10).

\begin{tabular}{l|c|c}
\hline & $A_{3} \times 10^{-3}$ & $B_{3}$ \\
\hline $\mathrm{C}_{10} \mathrm{E}_{8}$ & 0.963 & -6.21 \\
$\mathrm{C}_{11} \mathrm{E}_{8}$ & 0.872 & -6.44 \\
$\mathrm{C}_{12} \mathrm{E}_{8}$ & 0.800 & -6.80 \\
$\mathrm{C}_{13} \mathrm{E}_{8}$ & 0.717 & -6.98 \\
$\mathrm{C}_{14} \mathrm{E}_{8}$ & 0.660 & -7.26 \\
$\mathrm{C}_{15} \mathrm{E}_{8}$ & 0.597 & -7.46 \\
\hline
\end{tabular}

be expressed by the following ${ }^{12)}$ Eq. (11).

$\log \mathrm{cmc}=\frac{\Delta H_{m}}{2.303 R T}$

$$
-\frac{\Delta S_{m}}{2.303 R}+\log W
$$

By combining Eq. (10) corresponding to $\mathrm{C}_{n} \mathrm{E}_{8}$ with Eq. (11), $\Delta H_{m}$ and $\Delta S_{m}$ for micelle for= mation are calculated and are listed up together with $T \Delta S_{m}$ and $\Delta G_{m}$ in Table-3. As shown in Table-3, negative value for $\Delta G_{m}$ is given by the larger $T \Delta S_{m}$ value than $\Delta H_{m}$. This indi= cates that $T \Delta S_{m}$ value becomes a dominant factor for the micellization. In order to estimate the contribution of the increase of alkyl chain to the micellization, $\Delta H_{m}, T \Delta S_{m}$ and $\Delta G_{m}$ at 25.0 ${ }^{\circ} \mathrm{C}$ are plotted against the number of carbon atoms $(N)$ in the alkyl chain as shown in Fig.-6.

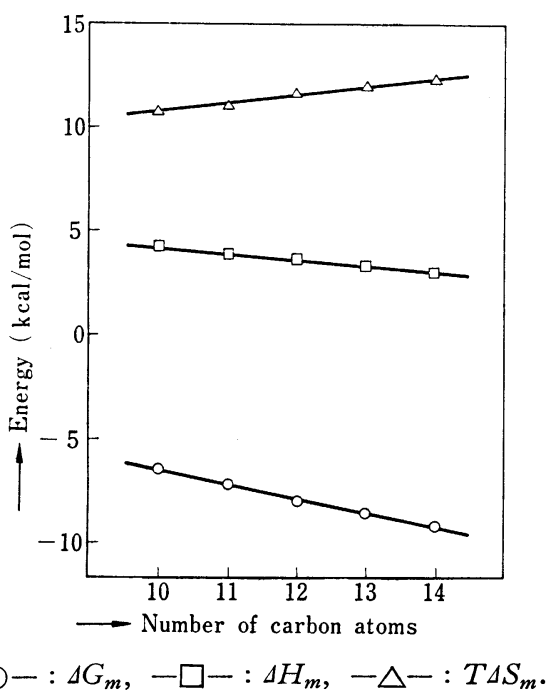

Fig.-6 Thermodynamic parameters of micel= lization at temperature of $25.0^{\circ} \mathrm{C}$ as a function of alkyl chain length for $\mathrm{C}_{n} \mathrm{E}_{8}$.

$\Delta G_{m}$ and $\Delta H_{m}$ values decrease with increasing carbon number, while the corresponding $T \Delta S_{m}$
Table-5 Thermodynamic parameters per methylene group for micellization at each temperature.

\begin{tabular}{|c|c|c|c|c|}
\hline $\begin{array}{l}\text { Temp. } \\
\left({ }^{\circ} \mathrm{C}\right)\end{array}$ & $\mid \begin{array}{l}\Delta G_{m}\left(-\mathrm{CH}_{2}-\right) \\
\left(\mathrm{kcal} \cdot \mathrm{mol}^{-1}\right)\end{array}$ & $\left\{\begin{array}{l}\Delta H_{m}\left(-\mathrm{CH}_{2}-\right) \\
\left(\mathrm{kcal} \cdot \mathrm{mol}^{-1}\right)\end{array}\right.$ & $\left\{\begin{array}{l}T \Delta S_{m}\left(\mathrm{CH}_{2}-\right) \\
\left(\mathrm{kcal} \cdot \mathrm{mol}^{-1}\right)\end{array}\right.$ & \begin{tabular}{|l}
$S_{m}\left(-\mathrm{CH}_{2}-\right)$ \\
$\left(\mathrm{cal}^{-\mathrm{mol}^{-1}}\right.$ \\
$\left.\cdot \mathrm{deg}^{-1}\right)$ \\
\end{tabular} \\
\hline 15.0 & -0.67 & -0.33 & 0.34 & 1.18 \\
\hline 20.0 & -0.68 & -0.33 & 0.35 & 1.19 \\
\hline 25.0 & -0.68 & -0.33 & 0.35 & 1.17 \\
\hline 30.0 & -0.69 & -0.33 & 0.36 & 1.19 \\
\hline 40.0 & -0.69 & -0.33 & 0.36 & 1.15 \\
\hline
\end{tabular}

values increase. From the slopes of each curve in Fig. -6, their parameters per methylene group $\left[\Delta G_{m}\left(-\mathrm{CH}_{2}-\right), \Delta H_{m}\left(-\mathrm{CH}_{2}-\right)\right.$ and $\left.T \Delta S_{m}\left(-\mathrm{CH}_{2}-\right)\right]$ are obtained as listed up in Table-5. From these results, it is evident that the summation of $\Delta H_{m}\left(-\mathrm{CH}_{2}-\right)$ and $T \Delta S_{m}\left(-\mathrm{CH}_{2}-\right)$ contributes to the micellization. (Received Jan. 5, 1981)

\section{Reference}

1) M.J. Schick and E.A. Beyer, J. Oil Chem. Soc., 40, 66 (1963).

2) M.J. Schick, S.M. Atlas, and F.R. Eirich, $J$. Phys. Chem., 66, 1326 (1962).

3) H. Lange, J. Colloid Sci., 20, 56 (1965).

4) H. Lange, Kolloid Z., 201, 131 (1965).

5) L. Hsiao, H.N. Dunning, and P.B. Lorenz, J. Phys. Chem., 60, 657 (1956).

6) P. Becher, J. Phys. Chem., 63, 1675 (1957).

7) P. Becher, "Nonionic Surfactants", Academic press, New York (1966) p. 483.

8) K. Meguro, Y. Takasawa, N. Kawahashi, Y. Tabata, and M. Ueno, J. Colloid Interface $\mathrm{Sci}$., in press. "Micellar Properties of a Series of Octaethyleneglycol $n$-Alkyl Ethers with Ho= mogeneous Ethylene Oxide Chain and Their Temperature Dependence".

9) H. Schott, J. Pharm. Sci., 58, 1521 (1969).

10) B.W. Barry and D.I.D. El Eini, J. Colloid Interface Sci., 54, 3 (1976).

11) J.E. Carless, R.A. Challis, and B.A. Mulley, J. Colloid Sci., 19, 201 (1964).

12) P. Molyneux, C.T. Rhodes, and J. Swarbrick, J. Trans. Faraday Soc., 61, 1043 (1965).

13) J.M. Corkill, J.F. Goodman, and R.H. Otte= will, J. Trans. Faraday Soc., 57, 1627 (1961).

14) J.M. Corkill, J.F. Goodman, and S.P. Harrold, J. Trans. Faraday Soc., 60, 202 (1964).

15) P.H. Elworthy and A.T. Florence, Kolloid Z., 195, 23 (1964).

16) J. Swarbrick, J. Pharm. Sci., 58, 147 (1969).

17) C. Mcauliffe, Nature (London)., 200, 1092 (1963).

18) A. Wishnin, J. Phys. Chem., 67, 2079 (1963).

19) Frank and Evans, J. Chem. Phys., 13, 507 (1945).

20) C. Tanford, "The Hydrophobic Effects", Wiley, New York (1973). 
アルキルニオクタキス(オキシエチレン)= エーテル同族体の水溶液表面とミセルの 性質及びそれらの温度依存性

上野 実・高沢要介・田端勇仁*・沢村隆光・ 川橋信夫・目黒謙次郎

東京理科大学理学部応用化学科 (新宿区神楽坂 1-3)

* 日本サーファクタント工業株式会社（板橋区蓮根 3-24-3)

アルキル=オクタキス(オキシエチレン)=エーテル同族 体 $\left(\mathrm{C}_{n} \mathrm{E}_{8}: n=10 \sim 15\right)$ の $\mathrm{cmc}$, 一分子当たりの面積及 び $\mathrm{cmc}$ での平衡表面張力值を, 15.0 から $40.0^{\circ} \mathrm{C}$ の温 度範囲で, 表面張力の濃度曲線から求めた。一分子当た りの面積及び $\mathrm{cmc}$ での平衡表面張力は, 炭素数の増加 とともに減少し, 偶数と奇数の炭素数の違いでジグザグ 曲線となった。このことは，偶数と奇数のお互いに異な った炭素数を持つ界面活性剂分子間の気一液界面におけ る分子配向性の違いによるものであると思われる。
一方，アルキル鎖長中の炭素数に対する $\log \mathrm{cmc} の$ プロットは, 直線関係を示し, 偶数と奇数の炭素数の差 異は，バルクの性質に対しては観察されなかった。ミセ ル形成に関する自由エネルギー変化 $\left(\Delta G_{m}\right)$ は, $\mathrm{cmc} の$ 温度依存性から計算された。また $\Delta H_{m}$ と $\Delta S_{m}$ の値は, $\log \mathrm{cmc}$ に対する温度の逆数のプロットから得られた直 線の傾きと切片とから, それぞれ求められた。これらの 結果から, $\mathrm{C}_{n} \mathrm{E}_{8}$ 系列のミセル形成に伴う $\Delta S_{m}$ は, $\Delta G_{m}$ に対して支配的に寄与することがわかる。さらに，メチ レン基 1 個当たりの $\Delta G_{m}\left(-\mathrm{CH}_{2}-\right), \Delta H_{m}\left(-\mathrm{CH}_{2}-\right), \Delta S_{m}$ $\left(-\mathrm{CH}_{2}-\right)$ 及び $T \Delta S_{m}\left(-\mathrm{CH}_{2}-\right)$ の值は, 炭素数に対する 各熱力学的関数の傾きから, それぞれ $-0.68 \mathrm{kcal} / \mathrm{mol}$, $-0.33 \mathrm{kcal} / \mathrm{mol}, 1.16 \mathrm{cal} / \mathrm{mol} \cdot \mathrm{deg}, 0.35 \mathrm{kcal} / \mathrm{mol}$ と計 算された。

この結果として，メチレン基1個当たりの $\Delta H_{m}$ $\left(-\mathrm{CH}_{2}{ }^{-}\right)$と $T \Delta S_{m}\left(-\mathrm{CH}_{2}-\right)$ は, ともにミセル形成に寄 与すると結論された。 